\title{
The Mistakes of a Public Communication in the Ebola Crisis in Spain
}

\author{
Rafael Barberá González \\ Universidad Complutense of Madrid \\ Victoria Cuesta \\ Universidad Complutense of Madrid
}

\begin{abstract}
This work analyzes the impact of the outbreak of hemorrhagic fever caused by the Ebola virus in Spain in the field of communication. The communication of such a crisis entails an interaction of information between individuals and institutions. Accuracy in the messages that are disseminated is key to the good resolution of the crisis. In this case of the Ebola crisis the impact in the Spanish media was very remarkable not only of the evolution of the crisis but also of the public information that were being made known by the authorities. The errors committed in this public communication, especially in the first institutional appearance, will be analyzed and possible solutions will be provided for future crises. In addition, the information behavior that was given in social networks by the authorities will be analyzed. To perform this work, bibliographical sources, data analysis and the media have been used.
\end{abstract}

Keywords: crisis - communication - public - ebola - media

\section{Introduction}

\section{Chronology}

When referring to the Ebola virus in Spain is August 7th, 2014 when the first case appears. On that date the religious Miguel Pajares is admitted to Hospital Carlos III after being repatriated from Liberia and dies on the 12th of that same month.

Later, in September, the priest Manuel García Viejo arrives infected to Hospital Carlos III and days later, also passes away.

Later, nursing assistant Teresa Romero becomes the first person to be infected with Ebola beyond Africa. She is transferred on October 6th to the Hospital Carlos III. That day is the first crisis of public communication, which will be analyzed in this work. He was discharged a month later, on November 6th.

\section{The crisis and its communication}

With the term crisis we can refer to a "natural or provoked, predictable or sudden situation, own or others, that threatens the image of the organization and jeopardizes its future actions; in addition, it alters internal and / or external relationships between itself and its publics or between itself and its members, and needs the execution of communication strategies to avoid that impact on the image or, if it occurs, to minimize the damage and try to reverse it as a positive asset" (Túñez, 2005).

In this particular case, some of the keys that characterize crises were given in a certain way. Thus, there was an alteration in the normal functioning of an organization -in this case, the Administration- by the surprise factor. There was also an emergency situation. And it also caused negative news streams to be resolved quickly. Organizations, instead of taking the initiative, are forced to react (Fita, 1999).

The emergence of this crisis, as well as a health problem for the Spanish population, posed a delicate situation for public institutions when it came to providing accurate information on what was happening. During the Ebola crisis the news that 
the citizens and the media were looking for were not the same. While the main interest of the former was the risk of infection they could have, in the second case they wanted to know if there had been foresight, if the established protocols had been fulfilled, etc.

When communicating in situations of risk, Suzanne Zoda made these recommendations in "Communication World" (in Wilcox et alii, 2007):

1.- Begin the dialogue with the public that may be affected as soon as possible. It is vital to build trust in the first contacts with anyone who is likely to be involved in the crisis.

2.- Investigate and actively identify what is of concern to people. Informal discussions, surveys, interviews and discussion groups are effective tools for assessing these issues.

3.- Recognize the public as a legitimate part of the process. Involve stakeholder groups in two-way communication and engage opinion leaders.

4.- Address issues of interest, even if they are not directly part of the project being developed.

5. Anticipate and prepare for hostility. It is necessary to identify those areas where agreements can be reached to work towards a common goal.

6.- Understand the needs of the media. You need to provide accurate information on time and respond to all requests.

7.- You have to be honored.

\section{Moment and context of communication}

When communicating a crisis situation, one of the main objectives is to inform the public in order to regain confidence. The lack of this can have serious consequences because if society is afraid of who should protect it, fear will increase. In addition, transparency must be given, that is, that the communication is truthful, complete, that it refers to the facts and that it is well understood. This transparency provides important advantages and can serve as an incentive to make decisions in a responsible manner. And, as for planning, if done properly, you get better results. "Risk communication should be incorporated into the planning of preparations for major events and in all aspects of a response to outbreaks."1.

The communication becomes more necessary in the first moments so that the different publics know the situation and can make decisions that lead to reduce the consequences. The first few hours are critical and if you do a bad management at that time can cause problems difficult to overcome. The proliferation of social networks makes that if the one in front of a crisis does not give fast explanations the social media will transfer doubts and questions to the society. The public shows a tendency to overestimate the risk if it lacks information.

When a crisis such as Ebola is reported, a number of rules exist, some of which have already been pointed out by Zoda, which must be taken into account according to the experts (Covello and Allen, 1998).

First, the public should be accepted as a partner. We must involve the parties with some interest in the matter. Decisions taken should be based on the magnitude of the risk but also on the concerns of the public.

Second, listen to the audience. It is important to find out the ideas of the public. Different techniques can be used for this purpose.

Thirdly, the communication must be honest, frank and open. Trust and credibility are basic to having good results. Risks should not be minimized or exaggerated.

Fourth, coordinate with other credible sources. It is important to communicate with other organizations that serve as allies. Employing time in coordination with other entities can be effective.

\footnotetext{
${ }^{1}$ In http://apps.who.int/iris/bitstream/10665/69370/1/WHO_CDS_2005_28_spa.pdf. Retrieved on July 29th, 2017.
} 
Fifth, the needs of all the media must be taken into account. They are the first to know and transmit information.

In the sixth place we must speak clearly and with compassion. Empathy in language is key. Data and risk information can be made available using examples that personalize them.

And, seventh, plan and evaluate efforts. The strategies are different according to the media, the objectives that are intended and the target audiences.

A key issue in communicating a crisis is knowing how to do it, because, as has been pointed out, the alterations involved mean that from the outset negative perceptions. "It is true, in any case, that the same causes do not have to create the same effects but it is also clear that they cause concern. For this reason communication is more effective if it is done when the crisis arises because the greater the knowledge of the facts, the greater the trust of the public"(Barbera and Cuesta, 2015).

As for the context, in the autumn of 2014 the Spanish sociopolitical situation was complex due to variables that are not the object of this study. In each relevant decision to be made by the administration there was a political component.

The case of the Ebola was no stranger. There were a few hours with a certain consensus to not politicize, but shortly after that generated a controversy in which all kinds of factors, beyond the strictly sanitary ones, entered. In the opinion of Professor Nombela, "the image of scientists and health care has been strengthened, while various policy makers have not been able to convey something fundamental: the success that means that the person infected with Ebola has overcome the infection" (Nombela, 2014).

\section{Methodology}

In this paper we analyze the repercussion of the contagion of the nursing assistant Teresa Romero from the field of institutional communication.

Different milestones have been chosen within the aforementioned communication to check whether or not errors occur when transmitting the information. They are mostly done by the Administrations.

It is part of the first press conference in which it is at the top of the authorities in the field of Spanish health. Not all the interventions are detailed but we do not focus on the Ana Mato ministry given that she was the most authoritative person in the comparison.

It also analyzes what has been done on social networks, especially on Twitter, since the creation of the first official account. Other studies address the typology of messages received by users but in this work it is preferred to value the initiative in communication through this network.

The Special Committee for the management of Ebola is also considered as a tool in the management of this crisis not so much from the strict sense of its usefulness as from the appropriate, or not, temporary moment of its creation.

The information provided to healthcare professionals and help for all audiences has been chosen as an element of analysis, in addition to warning messages to prevent the spread of bullshit.

The chosen period is the period of the first days since the arrival of the auxiliary Teresa Romero. Although it was a month in the hospital the initial days were key to determine the management of the communication object of this study. The content of the different actions is observed from an eminently qualitative and temporal point of view, regardless of how many were put into action.

\section{Analysis}

\section{Press conference}

On October 6, the Minister of Health, Ana Mato, attends a press conference together with the director general of Public Health, director general of Primary Care of the Community of Madrid and health professionals to explain that nursing assistant Teresa Romero is a health technician who cared for the patient Manuel Garcia Viejo. After detecting the symptoms and confirming the contagion, she was admitted to isolation in the La Paz Carlos III Hospital Complex. 
The minister wanted to highlight three aspects: "First, the absolute coordination that exists at both the national and international levels with the competent health authorities ... Secondly, Spain actively collaborates following all WHO recommendations, especially since the past August 8th was declared the Ebola virus as a public health emergency of international importance ... Thirdly, most importantly, to convey a message of tranquility to all citizens of our country. We have health professionals superbly trained to deal with such situations and with the technical and organizational capacity to deal with them"1.

This first press conference did not comply with what establishes any basic manual in crisis situations, which indicate as solutions that:

1. There must be a single spokesperson, qualified and credible. In this case seven people appeared.

2. There must be an information protocol. On that day, as the audience was heard, there was improvisation.

3. A crisis committee should be set up with a spokesperson. By the time of the press conference the crisis committee had not been formed. In addition this committee should have all the information about the crisis to make it known to the public.

4. The information must be transferred periodically and daily. This happened but later.

The management of the first days, including the appearance, was criticized by numerous experts. Some point out that: "During the first week (from October 6th to October 12th), the health authorities did the opposite of what was reasonable in a crisis: there was not a single spokesperson ..., it took a whole week to create a committee of crisis; the dispersion of information sources was evident ... "(Jurado and Jurado, 2015). Others point out that "although it was a success to convene the press conference quickly and, by extension, taking the initiative; due to the mistakes made, the appropriate knowledge in situations of institutional crisis was not transmitted either by the Minister or by the partners of the Ministry of Health and the Spanish Government "(Micaletto and Gallardo, 2015). And there are those who point out that of the 17 questions that were made at the press conference, the minister only responded to one, related to the resignations, and insistence of the journalist. "The role played by the minister Ana Mato seemed more that of a moderator, staying at all times in the background" (Monjas and Gil-Torres, 2017).

\section{Twitter}

In October 2014 the government of Spain created a Twitter account to, from that moment, inform all the public about Ebola. In addition to using it to point out precautions and point out recommendations would serve as an additional channel of communication. It was launched with the user @Info_Ebola_Es and in his first tweet could read "Welcome to

\footnotetext{
1 See the press conference at: http://www.elmundo.es/salud/2014/10/06/5432f21aca4741ad6e8b4574.html
} 
the Twitter account of the Special Committee for the management of the disease by Ebola virus".

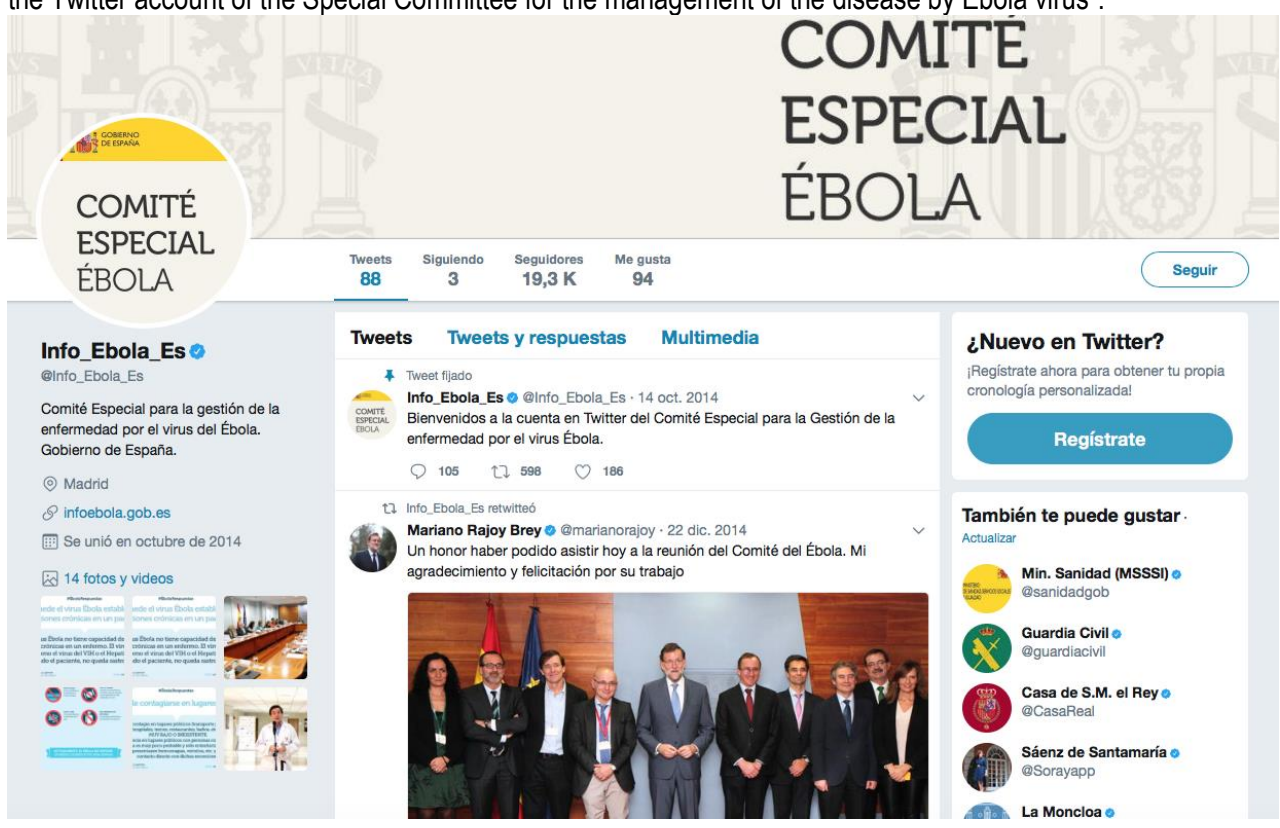

In the Ebola crisis that is addressed in this work this account on Twitter was created late. Social networks can be very useful if you make quick use of them.

In those first days, during the week of 6th to 12th October, however, several hagshtags appeared, for example, \#ebolaenespana, \#ebolaenespaña, \#salvemosaexcalibur, \#anamatodimision, \#JavierRodriguezDimision, \#teresaromero, \#TodosSomosTeresa and \#vamosamorirtodos. And some of them, according to Pirendo, a company that analyzes social networks professionally, became a trend on Twitter worldwide1.

As indicated by teachers Diaz Cerveró and Vázquez Barrio the messages published in this official account appeared when the crisis was at a very advanced stage. On the first day, on 14th, eleven messages were published, four on 15th, twenty on 16th, nine on 17th, four on 18th, three on 19th, six on 20th, ten on 21st, six on 22nd, five on 23rd, one on every day between 24th and 28th, two on 30th, one on November 1st and another on 5th. "In this case, the Government did not communicate the facts at the press conference it convened on that day, nor did it take advantage of the opportunity offered by social networks to respond quickly and effectively to the demand for information that existed. The official Twitter account was launched very late "(Díaz Cerveró and Vázquez Barrio, 2015).

\section{Special Committee for the Management of Ebola}

On October 10th, the Spanish government created the Special Committee for the Management of Ebola.

\footnotetext{
1 In http://pirendo.com/2014/10/14/ebolaenespana-analisis-twitter/. Retrieved on August 17th, 2017.
} 


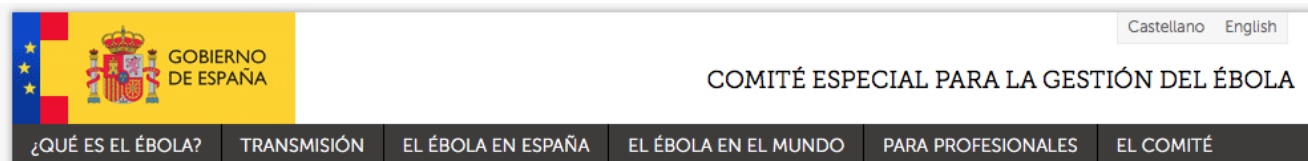

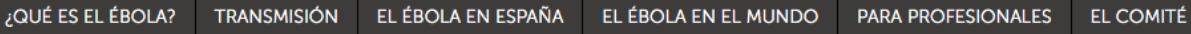

¿Qué es el Ébola?

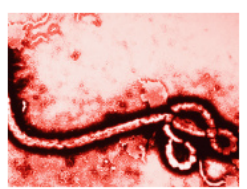

La enfermedad por el virus Ébola (antes conocida como fiebre del Ébola) es una patología hemorrágica febril causada por un virus del género Ebolavirus, que afecta a personas y a primates no humanos (monos, gorilas y chimpancés). Otros animales son portadores del virus, pero no desarrollan la enfermedad. Aún se desconoce el portador natural $[$.... ]

\section{Spanish aid worker repatriated from Mali at risk of} Ebola discharged

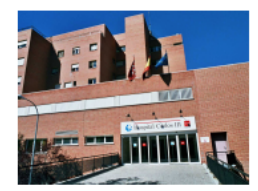

(Madrid, December 11th 2014).- The aid worker, a healthcare professional, had suffered an accident with biological material while attending an Ebola patient. Since this was a high-risk contact, the aid worker was repatriated to Spain and taken into the La Paz-Carlos III hospital complex on a preventative basis so that, in the event of $[\ldots]$

Recibe el alta la cooperante española repatriada desde Mali por riesgo de Ébola

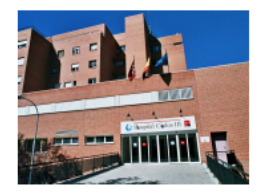

(Madrid, 11 de diciembre de 2014).- La cooperante española de Médicos Sin Fronteras que fue repatriada desde Mali el pasado 21 de noviembre por riesgo de haber contraído la enfermedad por el virus Ébola ha recibido hoy el alta tras haber cumplido los 21 dias de periodo de incubación en cuarentena hospitalaria sin haber desarrollado la $[\ldots]$
Buscar

Para buscar, escriba y presione enter

¿Qué es el Ébola?

¿Qué es el Ébola?

Sintomas de la enfermedad

Diagnóstico del Ébola

Preguntas Frecuentes

Video: ¿Qué es el Ébola?

Video: ¿Qué sintomas tiene el Ébola?

Transmisión

¿Cómo NO se contagia?

¿Cómo se contagia?

Prevención

Vacunas y Tratamientos

Riesgos de exposición

Video: ¿Cómo se transmite el Ébola?

Video: ¿Hay tratamiento para el Ébola?

Video: ¿Cómo puede prevenirse el contagio?

This Committee had among its main objectives the following:

1.- To monitor permanently the health of the infected person and of the cases of risk.

2.- Coordinate the mobilization of the necessary resources and resources so that Health professionals can do their work with the necessary support of the Administration.

3.- Promote inter-institutional and international cooperation.

4.- Establish information policy protocols for maximum transparency to Spanish society and information professionals.

5.- Analyze both the existing planning and all European and international action in the field of Ebola virus control.

Associated to this Committee was created another one of scientific character integrated by experts with the mission of assisting the Government in the making of decisions.

Audiences could find information on symptoms and diagnosis of Ebola on this page. In addition, data were provided on its possible transmission, such as how it could be spread, what the risks of exposure were, or anything related to vaccines and treatment. Users also had Ebola figures available in Spain and in the world, and lastly, there was a section dedicated to professionals.

Many experts believe that the creation of this Committee was a success but was slow to start. "Established the special committee for the management of Ebola, the distrust of health authorities was created ... The result was evident in the alarmism of some news and in the lack of information in depth" (Almendral, 2016). 
Once again, the need for faster communication to help build a relationship of trust between affected parties is highlighted.

\section{Information for professionals}

From the Ministry of Health, Social Services and Equality, information and documents were sent mainly to health professionals. On its website, under the heading 'Information on the outbreak of Ebola virus disease (EVE)', these protocols and reports were announced, among many others:

Evaluation of the risk to Spain of importation and transmission of Ebola virus disease from survivors of the epidemic in West Africa

Protocol of Action against suspected cases of Ebola Virus Disease (EVE)

Protocol of Action to an Aeroevacuation of cases of Illness by Ebola Virus

Procedure for handling cadavers of suspected Ebola virus cases

Action procedure to monitor displaced persons in countries affected by the Ebola outbreak

In this case, the information provided was complete and detailed, although it was directed almost exclusively to health professionals. The documents were revised as the authorities had new information.

\section{Help information and recommendations}

Both the profiles in the social networks of the National Police and of some Autonomous Community released the numbers of attention for the information on the Ebola, as well as making recommendations not to transmit unjustified alarms on this crisis. (Cortés, 2017).
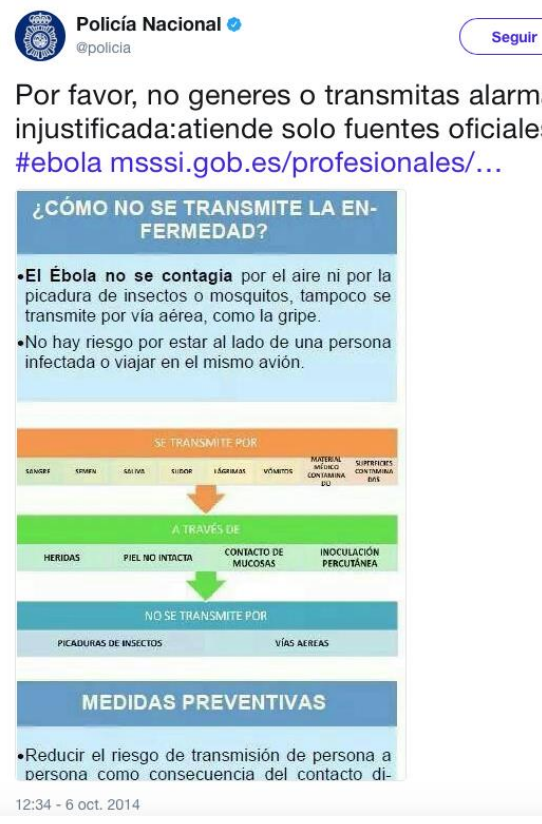

alarma

injustificada:atiende solo fuentes oficiales \#ebola msssi.gob.es/profesionales/...

In order to counteract the possible existence of inaccurate data or information on the Ebola crisis in social networks, the authorities made a call through their profiles so that audiences come to seek information from official sources.

From some media were given recommendations to avoid contributing to the bulo:

1.- Find information in official sources 
2.- Do not contribute to bullies by sharing alarmist information that is not confirmed. If you get a bulo and you detect it informs who sent it to you

3.- If an image is received with the news of a means of communication you can go to the website itself to verify the truth or to do that search in Google1

However, despite the efforts, loops appeared in the nets. "The state security forces had to raise the alarm:" You get whatsapp, tuit or mail from a security or health information course: Ignore it! Only official sources, such as

@Info_Ebola_Es \# ebola "by the National Police or" Circulan x \#Whatsapp \#bulos attaching FALSE media websites with FALSE \# Ebola alerts \#NODIFUNDAS "Civil Guard" (Calleja, 2016).

Again, as stated above, if the Administration had made early communication through social networks, these blunders could have been minimized.

\section{Conclusions}

1.- The outbreak of the Ebola was a fact of remarkable repercussion for all the publics. They demanded a lot of information not only through the media but also, and especially in the first moments, through the public authorities.

2.- The actions carried out by the administrations emphasize that, for the most part, they were taken when the crisis had already advanced. They were more actions of reaction than of anticipation. In the first hours and in the first days, crucial in every crisis, public communication was scarce and deficient.

3.- In the first press conference major errors were made. Among them stands out that one person is not identified as a spokesperson. In addition, it was not clear what the first actions to be taken from the Administration would be. And the messages that were sent did not serve to reassure the citizens.

4.- For the communication to have been effective, a management team for this crisis should have been formed from the outset. The agility to transmit information both in public appearances and in social networks would have been a fundamental tool in the resolution of this crisis. This would have avoided speculation on the part of the different publics.

5.- The success of Spanish health teams in this case was not accompanied by a good communication of institutional crisis. The delay in sending the messages made the perception of risk greater in the public.

\section{References}

[1] Almendral, G. (2016). En Debate sobre periodismo científico. El tratamiento informativo del brote epidémico del virus del Ébola. Cuadernos de la Fundación Dr. Antonio Esteve, pp. 18. Retrieved from http://www.esteve.org/?wpdmact=process\&did=MTU0OC5ob3RsaW5r

[2] Barberá, R., Cuesta, U. (2015). El virus del ébola: análisis de su comunicación de crisis en España. Opción, Año 31, $n^{\circ}$ especial 4. Pp $67-86$. Retrieved from http://produccioncientificaluz.org/index.php/opcion/article/view/20539

[3] Calleja, M. A. (2016). Contagio del elbola en Espanla: ejemplo de colmo no comunicar una crisis. En Mateos, C., Herrero, F.J. (coords), La Pantalla insomne (pp. 83-99). España: Sociedad Latina de Comunicación Social. Retrieved from http://www.revistalatinacs.org/15SLCS/2016_libro/003_Calleja.pdf

[4] Cortés, P. A. (2017). Comunicación de crisis: enfermedad del virus de ébola en España (Trabajo Fin de Master Oficial Comunicación de las Organizaciones). Universidad Complutense de Madrid.

[5] Covello, V. T., Allen, F. W. (1988). Seven Cardinal Rules of Risk Communication. Washington D.C., United States of America: U.S. Environmental Protection Agency, Office of Policy Analysis. Retrieved from http://www.wvdhhr.org/bphtraining/courses/cdcynergy/content/activeinformation/resources/epa_seven_cardina I_rules.pdf

[6] Díaz, E., Vázquez, T. (2015). El uso de Twitter por parte del Gobierno español durante la crisis del ébola. Miguel Hernández Communication Journal, n6, pp. 241 - 259.

[7] Fita, J. (1999). Comunicación en programas de crisis. Barcelona, España: Ediciones Gestio[n 2000, S.A.

\footnotetext{
1 https://verne.elpais.com/verne/2014/10/08/articulo/1412780742_000158.html. Retrieved on August 17th, 2017.
} 
[8] Jurado, E., Jurado, M. (2015). Los errores de comunicación en la crisis del ébola. Cuadernos de Periodistas, $n^{0} 29$, pp 90-99. Retrieved from http://www.cuadernosdeperiodistas.com/los-errores-de-comunicacion-en-lacrisis-del-ebolal

[9] Micaletto, J. P., Gallardo, L. (2015). La comunicación institucional en la crisis del ébola en Europa: el caso de la crisis española de 2014 en sus inicios. Revista Internacional de Relaciones Públicas, Vol. V, nº 9, pp. 89110. http://dx.doi.org/10.5783/RIRP-9-2015-06-89-110.

[10] Monjas, M., Gil-Torres, A. (2017). Comunicación institucional y tratamiento periodístico de la crisis del ébola en España entre el 6 y el 8 de octubre de 2014. Revista de Comunicación. Vol. XVI (1). Retrieved from http://udep.edu.pe/comunicacion/rcom/es/articulos/2017_1/5_Art097-121.html

[11] Nombela, C. (2014). Comunicación en las crisis, $A B C, 24$ de noviembre.

[12] Túñez, J. M. (2005): Informar en crisis. Proactivos desde la veracidad, en Gestión informativa de crisis en catástrofes marítima. La Coruña, España: Fundación Santiago Rey Fernández-Latorre, Xunta de Galicia.

[13] Wilcox, D. L., Cameron, G.T., Xifra, J. (2007): Relaciones públicas. Estrategias y tácticas. Madrid, España: Pearson Addison Wesley. 